\title{
Two cases of hypertensive Martorell's leg ulcers
}

\author{
B Bonfiglio*, G Dipaola, G Navarra \\ From de Senectute: Age and Health Forum \\ Catanzaro, Italy. 5-7 December 2009
}

\section{Background}

Martorell's ulcer is also a type of ischaemic ulcer occurring in hypertensive patients. The main features of this lesion are the following: location on the lower anteroexterior surface of the lower two thirds of the leg; pain far more severe than is expected given the size of the ulcer; significant arterial or venous disease; female-tomale predominance, association with no-controlled hypertension [2]. We describe two recent cases of hypertensive patients.

\section{Materials and methods}

1) A 78 years old female showed a painful ulceration on the lower-anterior surface of the left leg, sized $2 \times 4 \mathrm{~cm}$ (see Figure 1), covered by fibrinous exudates, demarcated margins and hyperaemic perilesional skin. She said she was not hypertensive and did not take antihypertensive drugs but, on clinical and physical examinations, her blood pressure was $195 / 90 \mathrm{mmHg}$ on the left arm and $187 / 85 \mathrm{mHg}$ on the right. Ultrasound showed moderate arteriopathy but good peripheral flow. In order to control blood pressure the patient was treated with combination ACE inhibitors and duretics, pentoxifylline $400 \mathrm{mg} /$ t.i.d., mesoglicane to improve microcirculation; topic treatment was made with enzymatic debridment and promogran wound dressing. Follow-up to 7,15 days we observed normalization of the arterial pressure and ulcer reducing size to $1,5 \times 2,5 \mathrm{~cm}$, the patient was pain free. 30 days follow-up ulcer is closed.

2) A male 63 years old, smoker, with a ulceration on the lower-lateral surface of the right leg, sized $1 \times 2 \mathrm{~cm}$ and other satellite smaller lesion $1 \times 0,4 \mathrm{~cm}$, covered by fibrinous exudates (see Figure 2). Ultrasound showed moderate arteriopathy but good peripheral flow. Blood pressure was $200 / 95 \mathrm{mmHg}$ on the left arm and $190 / 85 \mathrm{mHg}$ on the right. Patient was treated, also, with combination ACE inhibitors and diuretics, pentoxifylline, mesoglicane,

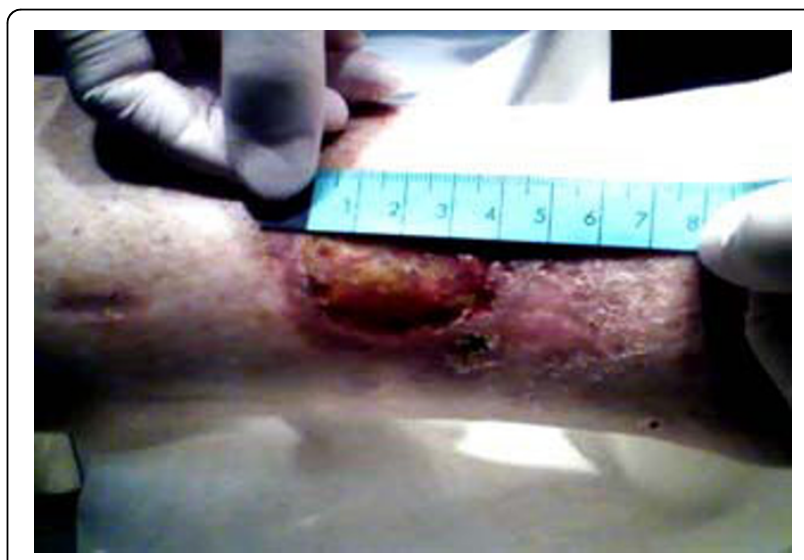

Figure 1

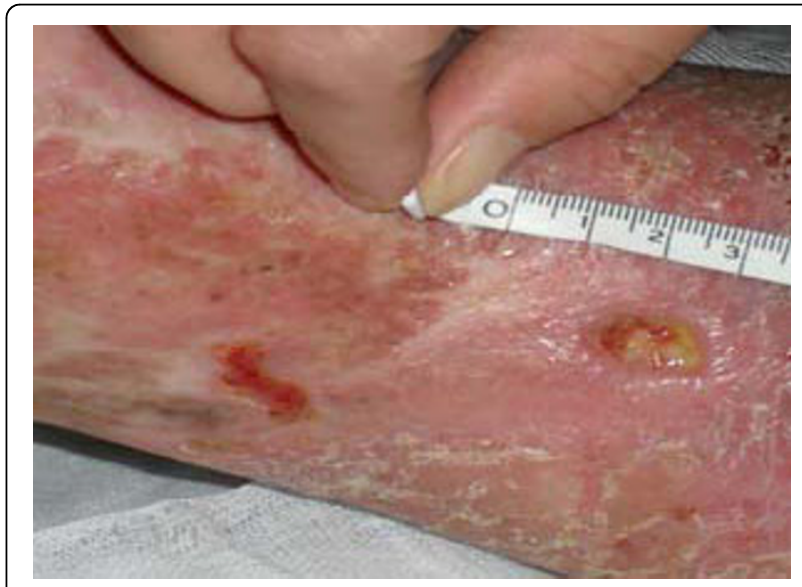

Figure 2

topic treatment with enzymatic debridment and promogran wound dressing. Follow up to 7,15 ,days showed normalization of pressure, no pain, $90 \%$ epithelialization of main ulcer and closure of the smaller. 


\section{Results and conclusions}

Martorell's ulcers are associated with long-standing or poorly controlled hypertension. Antihypertensive therapy controlling arterial pressure and topic treatment result in the resolution of these very painful lesions [1].

Published: 19 May 2010

\section{References}

1. Graves JW, Morris JC, Sheps SG: Martorell's hypertensive leg ulcer: case report and concise review of the literature. Journal of Human Hypertension 2001, 5:279-283.

2. Leu HJ: Hypertensive ischaemic leg ulcer (Martorell'sulcer): a specific disease entity. Int Angiol 1992, 11:132-136.

- Convenient online submission

- Thorough peer review

- No space constraints or color figure charges

- Immediate publication on acceptance

- Inclusion in PubMed, CAS, Scopus and Google Scholar

- Research which is freely available for redistribution 